\title{
Vernalization treatment induces site-specific DNA hypermethylation at the VERNALIZATION-A1 (VRN-A1) locus in hexaploid winter wheat
}

\author{
Abdul Rehman Khan ${ }^{1}$, Jérôme Enjalbert ${ }^{1}$, Anne-Charlotte Marsollier ${ }^{1}$, Agnès Rousselet ${ }^{1}$, Isabelle Goldringer ${ }^{1}$ \\ and Clémentine Vitte ${ }^{2^{*}}$
}

\begin{abstract}
Background: Certain temperate species require prolonged exposure to low temperature to initiate transition from vegetative growth to flowering, a process known as vernalization. In wheat, winter cultivars require vernalization to initiate flowering, making vernalization requirement a trait of key importance in wheat agronomy. The genetic bases of vernalization response have been largely studied in wheat, leading to the characterization of a regulation pathway that involves the key gene VERNALIZATION1 (VRN1). While previous studies in wheat and barley have revealed the functional role of histone modification in setting VRN1 expression, other mechanisms might also be involved. Here, we were interested in determining whether the cold-induced expression of the wheat VRN-A1 gene is associated with a change in DNA methylation.
\end{abstract}

Results: We provide the first DNA methylation analysis of the VRN-A1 gene, and describe the existence of methylation at CG but also at non CG sites. While CG sites show a bell-shape profile typical of gene-body methylation, non CG methylation is restricted to the large ( $8.5 \mathrm{~kb}$ ) intron 1 , in a region harboring fragments of transposable elements (TEs). Interestingly, cold induces a site-specific hypermethylation at these non CG sites. This increase in DNA methylation is transmitted through mitosis, and is reset to its original level after sexual reproduction.

Conclusions: These results demonstrate that VRN-A1 has a particular DNA methylation pattern, exhibiting rapid shift within the life cycle of a winter wheat plant following exposure to particular environmental conditions. The finding that this shift occurs at non CG sites in a TE-rich region opens interesting questions onto the possible consequences of this type of methylation in gene expression.

Keywords: VRN1, Vernalization, DNA methylation, Non CG methylation, Winter wheat, Transposable element, Triticum aestivum, Cold, Intron, Jorge, Sumaya

\section{Background}

Plants use environmental signals to modify and adapt their growth and development according to local climatic/ ecological conditions. A major step in plant life cycle is the transition from the vegetative to the reproductive stage that controls flowering, a critical trait for plant fitness. Seasonal cues, such as temperature and day-length, ensure that flowering coincides with favorable conditions to escape stress and maximize photosynthesis and seed production [1]. In temperate climate, certain species, including the temperate cereals (such as wheat and barley) and dicot species (such

\footnotetext{
* Correspondence: vitte@moulon.inra.fr

${ }^{2}$ CNRS, UMR de Génétique Végétale, Gif sur Yvette F-91190, France

Full list of author information is available at the end of the article
}

as Arabidopsis and sugar beet) need to be exposed to a period of prolonged low winter temperatures to accelerate the progression from vegetative to reproductive growth, a process known as vernalization [2-6]. Vernalization requirement is an adaptive trait that prevents flowering initiation prior to winter, which would otherwise result in severe frost damages on fragile flower meristems. The prolonged cold period is remembered over time, maintaining flowering stimulation when temperatures rise back during spring $[2,4,7]$. The vernalization signal is transmissible through mitosis but is reset in the next sexual generation therefore ensuring that descendants will be themselves able to respond to vernalization. 
In Arabidopsis, cold induces a transcriptional repression of the repressor of floral initiation FLOWERING LOCUS C (FLC). This repression is mediated by an epigenetic-based regulation in which the FLC chromatin state is switched from an actively transcribed state (with high levels of histone $\mathrm{H} 3$ acetylation and histone $\mathrm{H} 3$ lysine $4 \mathrm{di}$ - and trimethylation) to a repressed state (with high levels of histone $\mathrm{H} 3$ lysine 9 dimethylation, histone H4 arginine 3 symmetrical dimethylation, and histone H3 lysine 27 di- and trimethylation) $[3,8,9]$. This transcriptional repression is then maintained over cell divisions by mitotic inheritance of the repressive histone modifications [10], but is reset during reproduction, thus allowing progeny to be competent to respond to vernalization [11]. Molecular basis of such transient memory of a cold period during plant development has been recently described in other species. In temperate cereals such as the triticeae, response to vernalization is mediated by the stable induction of a floral activator, VERNALIZATION1 (VRN1) [4,12-14]. VRN1 encodes a FRUITFULL-like MADS-box transcription factor that is required for the initiation of reproductive development at the shoot apex [15-17]. VRN1 is central in the vernalization pathway [18] as it down regulates the floral repressor VERNALIZATION2 (VRN2) but also interacts with other flowering pathways, allowing long-day induction of the floral activator FLOWERING LOCUS T-like 1 (FT1) to accelerate subsequent stages of floral development [4,19-22]. The expression of VRN1 is induced by cold treatment, is maintained when cold treatment is released, and is reset in the next generation $[12-14,19,23,24]$, some characteristics that point out to a possible epigenetic regulation.

The epigenetic regulation of $H v V R N 1$, the VRN1 gene of barley (Hordeum vulgare), has been assessed through the analysis of histone post-translational modifications [25]. Vernalization increases active histone marks for transcription (H3K4me3, histone 3 lysin 4 trimethylation) in two regions located in exon one and the beginning of intron 1 , while decreasing silent marks (H3K27me3, histone 3 lysine 27 trimethylation) in 6 regions located from the promoter to the end of intron 1 . In a more recent study [26], histone acetylation of intron 1 was also shown to be involved in the regulation of the gene: acetylation levels of histones 3 and 4 increase during cold treatment in intron 1 , and sodium butyrate, a histone deacetylation inhibitor, induces an increase in HvVRN1 expression. Altogether, this suggests that in barley vernalization induces histone modifications associated with an active chromatin state, which correlates with an increase in VRN1 transcripts. These changes are retained posterior to vernalization, providing a molecular hypothesis for the epigenetic-based memory of vernalization in barley.

In hexaploid wheat (Triticum aestivum), analysis of H3K4me3 and H3K27me3 histone modifications of the
TaVRN1 promoter region (from two subregions located near the ATG and $1 \mathrm{~kb}$ upstream of it) in winter and spring wheat revealed no significant changes for H3K27me3 following vernalization in both genotypes [27]. However, vernalization caused an enrichment of H3K4me3 in winter wheat while a decrease of this histone modification was observed in spring wheat. Altogether, these results suggest that vernalization promotes an active state of the TaVRN1 chromatin in winter wheat and a reduction of this active state in spring wheat. These results are consistent with the relative abundance of TaVRN1 mRNA in winter and spring wheat and suggest that the wheat vernalization responsive gene VRN1 is regulated, at least in part, by histone methylation at the promoter. Genetic studies have shown that, besides the promoter region, internal regions of $V R N-A 1$ such as intron 1 are also involved in the differential regulation observed between spring and winter wheat [28]. This, together with the results obtained for barley, suggests that an epigenetic regulation of the internal regions of the gene could be involved in the regulation of $V R N-A 1$.

However, these studies of the VRN1 regulation were limited to the analysis of histone marks, and did not allow for testing the potential role of DNA methylation in the cereal vernalization process. While DNA methylation could not explain the expression changes observed for FLC in Arabidopsis [29], studies on sugar beet (Beta vulgaris) revealed that the flowering repressor $B v F L C$ is hypermethylated and decreases during vernalization in genotypes sensitive to vernalization, this effect being more pronounced for longer duration of cold treatment [5]. The differences observed between Arabidopsis and sugar beet suggest that the ability to respond to vernalization may have been acquired through different molecular mechanisms within dicotyledonous plants and highlight the need to better characterize the role of DNA methylation in the molecular mechanisms involved in the response to vernalization for other species. In particular, the role played by DNA methylation in the vernalization response of monocotyledonous plants such as cereals needs to be investigated.

DNA methylation on cytosines is a well studied epigenetic mark in plants. It is involved in the regulation and transcriptional silencing of genes and transposable elements (TEs), respectively, and plays major roles in cellular differentiation and genome evolution [30,31]. Inherited methylation changes also likely play a role in plant phenotypic evolution [32,33]. While DNA methylation mainly occurs at $\mathrm{CG}$ sites in animal genomes, it can affect cytosines in $\mathrm{CG}, \mathrm{CHG}$ and $\mathrm{CHH}$ contexts ( $\mathrm{H}$ denotes A, $\mathrm{C}$ or $\mathrm{T}$ ) in plants $[34,35]$. Repeated sequences such as TEs are heavily methylated at the three cytosine contexts, whereas DNA methylation in the body of the genes (gene body methylation) is less dense and mainly limited to CG sites [20,35-38]. Whereas the mechanisms underlying the 
establishment and maintenance of DNA methylation are now relatively well understood, little is known about their dynamics during the plant and animal life time. Several studies have focused on the biological relevance of DNA methylation dynamics in plant response to biotic stresses $[39,40]$ but its relevance in the response to abiotic cues remains largely unknown.

In this article, we investigated the effect of vernalization on the DNA methylation profile of the VRN-A1 gene in winter wheat. We focused on studying the cellular memory of coldinduced DNA methylation after the environmental stimulus was removed. For this, we analyzed the DNA methylation pattern of VRN-A1 on plants submitted or not to 45 days-long cold treatment inducing the expression of $V R N-A 1$ gene and placed back in greenhouse conditions for 10 additional days.

Our study indicates that cold induces an increase in DNA methylation within the body of the VRN-A1 gene, which is reset in the next generation, thus highlighting a first case of environmentally-induced epigenetic change in wheat. Whether the observed increase in DNA methylation explains the increase in expression of the $V R N-A 1$ gene or is simply correlative remains to be elucidated. Nevertheless, the finding that cold-induced hypermethylation specifically affects non CG sites located in TE fragments from the
$8.5 \mathrm{~kb}$ long intron 1 suggests that TE fragments may facilitate the DNA hypermethylation process observed.

\section{Results}

\section{Overall DNA methylation pattern of VRN-A1 in} non-vernalized plants

DNA methylation pattern of the $V R N-A 1$ gene was investigated using the bisulfite conversion method, which allows for the quantitative detection of methylation level for each cytosine of a PCR-amplified fragment. To analyze the overall methylation pattern of the $V R N-A 1$ gene, we analyzed 9 fragments located along the $V R N-A 1$ gene, covering $21 \%$ of this $12 \mathrm{~kb}$ gene (Table 1). DNA methylation of these 9 fragments was investigated on two genotypes, three biological repetitions and two treatments (with and without 45 days exposure at $4^{\circ} \mathrm{C}$, Figure 1 ). Because these experiments would be facilitated by the use of a cost- and labor-effective method to quantify DNA methylation, we used direct reading of PCR Sanger sequence chromatograms to quantify DNA methylation at each cytosine site after bisulfite conversion and PCR amplification (see Additional file 1 for details). Design of primers fitting the bisulfite treatment requirements for a hexaploid genome was not trivial, and about $50 \%$ of the

Table 1 Characteristics of PCR amplicons used for bisulfite analysis

\begin{tabular}{|c|c|c|c|c|}
\hline Fragment number & Primer name & Primer sequence $\left(5^{\prime}-3^{\prime}\right)$ & $\begin{array}{c}\text { Position of fragment } \\
\text { within the VRN-A1 gene } \\
\text { (bp from start of Genbank accession AY747600) }\end{array}$ & $\begin{array}{l}\text { Size of amplified } \\
\text { fragment } \\
\text { (bp) }\end{array}$ \\
\hline \multirow[t]{2}{*}{$0.01 k^{(1)}$} & $0.01 \mathrm{k}-\mathrm{F}$ & AAATGATTTGGGGAAAGTAAAATT & $100-311$ & 212 \\
\hline & $0.01 \mathrm{k}-\mathrm{R}$ & AAAAAA $\Pi \Pi \Pi A A A A A A A T C T A A C C C$ & & \\
\hline \multirow[t]{2}{*}{$1.2 k^{(1)}$} & $1.2 \mathrm{k}-\mathrm{F}$ & ATTAAATTTGTGTITGTTGTITGA & $1221-1468$ & 248 \\
\hline & $1.2 \mathrm{k}-\mathrm{R}$ & ААСТСТСТАСТППТАAТПТААСТСТТ & & \\
\hline \multirow[t]{2}{*}{$2.2 \mathrm{k}$} & $2.2 \mathrm{k}-\mathrm{F}$ & GGGGATAAGTAATTGTTATGTITTG & $2259-2490$ & 233 \\
\hline & $2.2 \mathrm{k}-\mathrm{R}$ & ATCCAAAAAATCAACAAACTACAT & & \\
\hline \multirow[t]{2}{*}{$6.8 \mathrm{k}(\mathrm{a})^{(2)(3)}$} & $6.8 \mathrm{k}(\mathrm{a})-\mathrm{F}$ & TTGTITGTATGTGAGTAGATTGGA & $6847-7147$ & 301 \\
\hline & $6.8 \mathrm{k}(\mathrm{a})-\mathrm{R}$ & AACTACTCСТССАССТТАТАСCAA & & \\
\hline \multirow[t]{2}{*}{$7.6 \mathrm{k}^{(4)}$} & $7.6 \mathrm{k}-\mathrm{F}$ & TGAGGAGGTTGGAAGTATTAAGTA & 7679-7393 & 315 \\
\hline & $7.6 \mathrm{k}-\mathrm{R}$ & TACACCCCTACAAAACTAAATCTT & & \\
\hline \multirow[t]{2}{*}{$9.2 \mathrm{k}$} & $9.2 \mathrm{k}-\mathrm{F}$ & ATGTAGTATGGATAAAATITITGAA & $9203-9711$ & 509 \\
\hline & $9.2 \mathrm{k}-\mathrm{R}$ & TТА ТTACTAAACCCТТCAAAAACTC & & \\
\hline \multirow[t]{2}{*}{$10.1 k$} & $10.1 \mathrm{k}-\mathrm{F}$ & GTTGTAGTITTAATTGAGGGATT & 10130-10512 & 383 \\
\hline & $10.1 \mathrm{k}-\mathrm{R}$ & ACСССТАТССАТАAСТАAСТСТ & & \\
\hline \multirow[t]{2}{*}{$10.5 k$} & $10.5 \mathrm{k}-\mathrm{F}$ & AATITGTTTGGGATTAAAGGTT & $10592-10939$ & 340 \\
\hline & $10.5 \mathrm{k}-\mathrm{R}$ & CAАAАТССТСТСССАТАAАATAC & & \\
\hline \multirow[t]{2}{*}{$11.7 \mathrm{k}$} & $11.7 \mathrm{k}-\mathrm{F}$ & GTGTTYGTITGGTTGTGTAGT & $11792-12048$ & 257 \\
\hline & $11.7 \mathrm{k}-\mathrm{R}$ & ACTCTAATICTITCCTITCCC & & \\
\hline
\end{tabular}

Bold letters in the sequence represent primer positions matching cytosines, which were considered as non methylated and therefore converted into thymines after bisulfite treatment (Cs were changed to Ts in forward primers and Gs to As in reverse primers). ${ }^{(1)}$ Primer pairs that were not genome A specific;

${ }^{(2)}$ Fragment for which several primer pairs with different $\mathrm{C} / \mathrm{T}$ content were designed (see Additional file 1); ${ }^{(3)}$ While corresponding PCR amplicon contains a fragment of the Jorge transposon, the reverse primer does not overlap the annotation of this element. The closest Jorge element found shares only $76 \%$ nucleotide identity with this amplicon; ${ }^{(4)}$ While the two primers are included within the Sumaya annotation, the closest Sumaya element found shares only $81 \%$ nucleotide identity with this amplicon. 


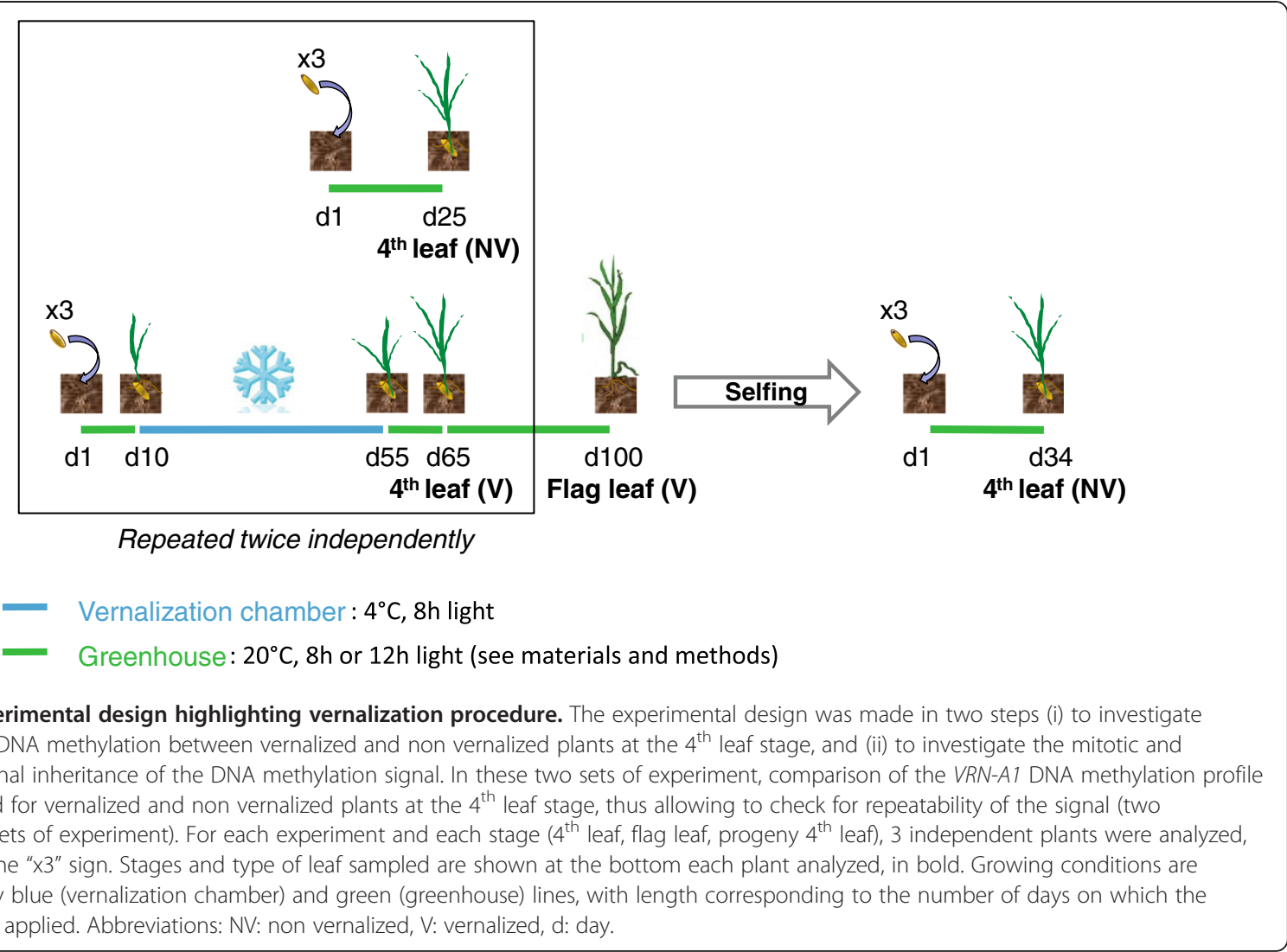

PCR designed were either not amplifying or leading to poor sequencing traces. In particular, the middle of intron 1 and the region located between exons 4 and 8 could not be covered by bisulfite-PCR assays. We therefore used methylsensitive PCR assays (5 fragments) to investigate the DNA methylation profile of these regions (Table 2 for enzyme specificity and 3 for PCR amplicons). We also used this technique to validate results for 3 bisulfite-PCR fragments with contrasted DNA methylation patterns (Table 3, and Additional file 1 for comparison of the two patterns).

Analysis of these 17 fragments (covering 540 cytosines) on one plant from the G1 genotype grown in non vernalizing conditions revealed that most fragments $(0.0 \mathrm{k}, 0.01 \mathrm{k}$, $1.2 \mathrm{k}, 1.6 \mathrm{k}, 2.2 \mathrm{k}, 3.0 \mathrm{k}$ and $11.7 \mathrm{k}$ ) were not methylated. For the remaining fragments, DNA methylation was either restricted to CG sites (fragments $9.2 \mathrm{k}$ to $10.5 \mathrm{k}$ ), or was observed in all CG, CHG and $\mathrm{CHH}$ contexts (fragments $4.0 \mathrm{k}$, $6.8 \mathrm{k}(\mathrm{a})$ and $7.6 \mathrm{k})$. These results indicate that the DNA methylation of the $V R N-A 1$ gene is heterogeneous along its sequence, with an absence of methylation at the start and end, while the region extending from the middle of intron 1 to the start of exon 4 is highly methylated (Figure 2). DNA methylation rates at the different cytosine contexts (Figures 2 and 3) were similar to what has been observed in Arabidopsis and maize (typically $80-100 \%$ for CGs, 20$100 \%$ for CHGs and up to $10 \%$ for CHHs; $[38,42,43]$.
Vernalization induces both hypermethylation at the end of VRN-A1 intron 1 and gene transcription increase

Comparison of DNA methylation profiles of one vernalized and one non-vernalized plant of the G1 genotype for all bisulfite PCR fragments revealed a difference of methylation level only for fragments $6.8 \mathrm{k}(\mathrm{a})$ and $7.6 \mathrm{k}$. Further investigation of the DNA methylation pattern of these two fragments on two additional biological replicates of genotype G1 and three biological replicates of genotype G2 showed that patterns were homogeneous among non-vernalized plants, and among vernalized plants, and confirmed the difference observed between vernalized and non vernalized plants (Figure 3, exp. 1). CG sites show an average methylation rate higher than $90 \%$ in both conditions, with no significant variation between treatments. In contrast, CHG and $\mathrm{CHH}$ sites showed a significant increase in DNA methylation in vernalized plants (Figure 3, exp.1).

Analysis of cytosines taken individually (Figure 4 and Additional file 2: Figure S1) revealed that all CG sites are methylated above $90 \%$ in both conditions, while all CHG sites are methylated in non vernalized plants but show a significant increase in DNA methylation following vernalization (except sites 148 and 250 of fragment $6.8 \mathrm{k}$ (a) for which the increase is visible but not significant). Interestingly, while only a small fraction of $\mathrm{CHH}$ sites is methylated $(11.3 \%$ and $0.4 \%$, in fragment $6.8 \mathrm{k}(\mathrm{a})$ and 
Table 2 Recognition sites and methylation sensitivities of the restriction enzymes used

\begin{tabular}{ccc}
\hline Enzyme & Recognition site & Sensitivity to methylation \\
\hline Bfa I & $5^{\prime}-\mathrm{CTA} \mathrm{G}^{\mathbf{\top}} \mathrm{T}^{\prime}$ & none \\
& $3^{\prime}-\mathrm{G} \mathrm{AT}_{\mathbf{A}} \mathrm{C}-5^{\prime}$ & \\
& & \\
\hline
\end{tabular}

BstU I 5'-CG $\mathrm{CG}-3$,

CG

$$
3^{\prime}-\mathrm{GC}_{\mathbf{A}} \mathrm{GC}-5^{\prime}
$$

$$
\begin{array}{ll}
\text { Hpa II } & \text { 5'-C'CG G-3' } \\
& 3^{\prime}-\mathrm{G} \mathrm{GC}_{\mathbf{\Lambda}} \mathbf{C}-5^{\prime}
\end{array}
$$$$
\text { CG }
$$

$$
\text { Msp I }
$$

$$
\text { 5'-C'CG G-3' }
$$

PspG I

$$
\begin{aligned}
& \text { 5'- } \mathbf{\nabla} \text { CCHGG -3' } \\
& \text { 3'- GGWCC -5' }
\end{aligned}
$$

Arrowheads indicate enzymes cutting sites and bold Cs show methylation sensitive sites.

$7.6 \mathrm{k}$, respectively), no additional methylated site was found. Rather, a significant increase of DNA methylation was observed for almost all sites that were methylated in non-vernalized conditions (Figure 4). Comparison of the two genotypes revealed very similar methylation patterns: only sites 118 and 165 of fragment $6.8 \mathrm{k}(\mathrm{a})$ showed significant differences between the two genotypes (G1 showed 4.8 and 1.5 times higher DNA methylation than G2 at sites 118 and 165 respectively; data not shown).

Taken together, these results reveal that, at the end of intron 1, vernalized plant show an increase in methylation at $\mathrm{CHG}$ and $\mathrm{CHH}$ sites that is restricted to the sites that are also partially methylated in nonvernalized plants. On the contrary, almost all CG sites are highly methylated in both conditions, and are therefore not impacted by the vernalization treatment. These observations were confirmed on a second set of experiments (Figure 3, exp. 2), indicating that the shift in DNA methylation observed is repeatable.

Because the expression of the VRN-A1 gene is known to increase following vernalization [23], our data suggested a positive correlation between DNA methylation and gene transcription. To identify whether the DNA methylation shift observed following vernalization was correlated to the expression of the VNR-A1 gene, we performed qRT-PCR for both vernalized and nonvernalized conditions, using the same leaf powder used for DNA methylation analyses. qPCR results indicate a $10 \mathrm{Ct}$ change between vernalized and non vernalized plants, pointing to a 1000 fold increase of $V R N-A 1$ leaf mRNA levels following vernalization (Figure 5). This expression increase is associated with the DNA methylation shift observed, with $V R N-A 1$ being expressed when the gene shows higher gene body methylation.

The high level of DNA methylation observed in vernalized plants is maintained through mitosis but is reset in the next generation

To verify the results obtained on $4^{\text {th }}$ leaf and to study the mitotic and transgenerational transmission of the modifications in DNA methylation observed following vernalization, a second set of plants was grown up to flowering maturity. DNA methylation pattern of fragments $6.8 \mathrm{k}(\mathrm{a})$ and $7.6 \mathrm{k}$ was analyzed on fourth leaf and flag leaf samples (Figures 1 and 3). No significant difference was observed between the $4^{\text {th }}$ leaf and the flag leaf samples (Figure 3), thus revealing that the DNA methylation profile observed is maintained through mitosis.

Vernalized plants of this second set were selfed, and the progeny was analyzed in non-vernalizing conditions at the fourth leaf stage (Figure 1). DNA methylation profile analysis of fragments $6.8 \mathrm{k}(\mathrm{a})$ and $7.6 \mathrm{k}$ revealed that all cytosines show a methylation profile typical of non vernalized plants (Figure 3), therefore providing evidence that the increase in DNA methylation induced by vernalization is reset in the next generation.

\section{The sequence of winter allele of VRN-A1 harbor TE} fragments not found in VRN-B1 and VRN-D1 copies

TE annotation within the $V R N-A 1$ winter genotype sequence using the most recently updated wheat transposable element database [44] revealed the presence of several TE fragments, most of which are located within the second half of intron 1 (Figure 2). Interestingly, the region covered by these TEs is the region showing the highest methylation level, harboring methylated Cs from CG context, but also from $\mathrm{CHG}$ and $\mathrm{CHH}$ contexts. In particular, fragments $6.8 \mathrm{k}(\mathrm{a})$ and $7.6 \mathrm{k}$ that show a difference in DNA methylation level between vernalized and non-vernalized plants also harbor pieces of TEs: amplicon 6.8(a) contains a fragment of the CACTA-like TIR transposon Jorge (126 bp of the internal part of the element, from base 6854 to base 6979) while amplicon $7.6 \mathrm{k}$ is fully covered by a piece of the gypsy-like LTR retrotransposon Sumaya (952 bases of the LTR, from position 7213 to 8164). Annotation of $V R N-B 1$ and $V R N-D 1$ genes and comparative analysis with $V R N-A 1$ 
Table 3 Description of amplicons characteristics used for restriction enzyme analyses

\begin{tabular}{|c|c|c|c|c|c|c|c|}
\hline \multirow[t]{2}{*}{$\begin{array}{l}\text { Fragment } \\
\text { number }\end{array}$} & \multirow[t]{2}{*}{ Primer name } & \multirow[t]{2}{*}{ Sequence $\left(5^{\prime}-3^{\prime}\right)$} & \multirow{2}{*}{$\begin{array}{l}\text { Position of fragment within the } \\
\text { VRN-A1 gene (bp from start of } \\
\text { Genbank accession AY747600) }\end{array}$} & \multirow[t]{2}{*}{$\begin{array}{l}\text { Size of amplified } \\
\text { fragment (bp) }\end{array}$} & \multicolumn{3}{|c|}{$\begin{array}{l}\text { Number of restriction site } \\
\text { within amplicon for: }\end{array}$} \\
\hline & & & & & Mspl & PspGI & BstUI \\
\hline \multirow[t]{2}{*}{$0.0 \mathrm{k}$} & VRN_1_A_pr_F* & GAAAGGAAAAATTCTGCTCG & $44-527$ & 483 & 8 & 1 (n.a.) & 3 \\
\hline & VRN_1_ex1_R* & TGCACCTTCCCSCGCCCCAT & & & & & \\
\hline \multirow[t]{2}{*}{$1.6 \mathrm{k}$} & $1.6 \mathrm{k}-\mathrm{F}$ & GCCTCCACGGTITGAAAGTA & $1695-2358$ & 663 & 1 & 0 & 2 \\
\hline & $1.6 \mathrm{k}-\mathrm{R}$ & ATCTCAAGATITTAGTTCCGATCCT & & & & & \\
\hline \multirow[t]{2}{*}{$3.0 \mathrm{k}$} & $3.0 \mathrm{k}-\mathrm{F}$ & TGCTGCAGTGATATITTGTTAGC & $3030-3710$ & 680 & 0 & 1 & 0 \\
\hline & $3.0 \mathrm{k}-\mathrm{R}$ & TGATGGGTCATAAGGTITGC & & & & & \\
\hline \multirow[t]{2}{*}{$4.0 \mathrm{k}$} & $4.0 \mathrm{k}-\mathrm{F}$ & CTTCCTTGGTGGGCTGTG & $4003-4607$ & 604 & 1 & 0 & 1 \\
\hline & $4.0 \mathrm{k}-\mathrm{R}$ & TGGCTCTCCACCACAATACC & & & & & \\
\hline \multirow[t]{2}{*}{$5.0 \mathrm{k}$} & $5.0 \mathrm{k}-\mathrm{F}$ & GGCTAAGATCGTGAGGAAGG & $5014-5648$ & 634 & 0 & 1 & 0 \\
\hline & $5.0 \mathrm{k}-\mathrm{R}$ & TGACTAGCACCACATCAATCG & & & & & \\
\hline \multirow[t]{2}{*}{6.8 k (b) } & $6.8 \mathrm{k}(\mathrm{b})-\mathrm{F}$ & GCGGCATCATCTTCTTGC & $6834-7148$ & 314 & 1 & 0 & 2 \\
\hline & $6.8 k(b)-R$ & GGCTACTCCTCCACCTTATGC & & & & & \\
\hline \multirow[t]{2}{*}{$9.8 \mathrm{k}$} & $9.8 \mathrm{k}-\mathrm{F}$ & TCTCCAGTCCTTCGGATTGT & $9871-10489$ & 618 & 1 & 1 & 0 \\
\hline & $9.8 \mathrm{k}-\mathrm{R}$ & GGCTITTGGGTTTCATCTCC & & & & & \\
\hline \multirow[t]{2}{*}{$11.0 \mathrm{k}$} & $11.0 \mathrm{k}-\mathrm{F}$ & AATGATTTGATACAGCAGCACAATA & $11028-11710$ & 682 & 1 & 1 & 0 \\
\hline & $11.0 \mathrm{k}-\mathrm{R}$ & ACCAATTCAAAAGATGGTTACTTGA & & & & & \\
\hline
\end{tabular}

*PCR primers from [41]. Abbreviations: n.a.: not analyzed.

showed that the Sumaya element is specific from the A genome VRN1 copy (Figure 6). Comparison of the Jorge and Sumaya fragments located in VRN-A1 with sequences from other Jorge and Sumaya elements extracted from chromosome $3 \mathrm{~B}$ revealed that they share $76 \%$ and $81 \%$ identity with the closest copy, respectively. This, together with the fact that they are truncated TEs, suggests that these sequences have evolved from ancient insertions.

\section{Discussion}

The VRN-A1 gene is body methylated and harbors additional non-CG methylation in intron 1

The 17 assays ( 9 bisulfite-PCR assays and 8 methylsensitive restriction-PCR assays) applied over the whole $V R N-A 1$ gene sequence revealed that this gene shows a non homogeneous and contrasted methylation pattern: while the $5^{\prime}$ and $3^{\prime}$ extremities are not methylated, the inside of the gene is highly methylated (Figure 2). In particular, methylation at CG sites shows a bell shape pattern with high methylation inside the gene and a low or absent methylation level at the extremities, a pattern commonly observed in plants and animals, and that is referred to as "gene body methylation" [34-37]. In $A$. thaliana, body-methylated genes tend to be longer and contain more exons than unmethylated genes [45]. Accordingly, VRN-A1 is a long gene, with a total size of $12,233 \mathrm{bp}$ and 8 exons (as compared to an average size of $3.3 \mathrm{~kb}$ and average exon number of 5.6 for wheat genes, [44].

In addition to the classical bell-shaped CG methylation profile, VRN-A1 also presents a strongly methylated zone at the end of intron 1 (fragments $6.8 \mathrm{k}(\mathrm{a})$ and $7.6 \mathrm{k}$ ) which involves almost complete methylation at CG sites and intermediate levels of methylation at $\mathrm{CHG}$ and $\mathrm{CHH}$ sites, a pattern that is commonly associated with TE sequences. While genes are mainly methylated at CG sites through the action of MET1 [46], DNA methylation at TEs is reinforced by the action of the RNA-directed DNA methylation (RdDM) machinery [31], which involves the production of 24 nt heterochromatic small RNAs that direct the de novo methylation machinery to $\mathrm{TE}$ sequences at CG, CHG and $\mathrm{CHH}$ sites. This epigenetic mechanism limits TE transposition and therefore protects the genome from insertional mutations [47-50]. Indeed the annotation of the VRN-A1 sequence revealed the presence of several $\mathrm{TE}$ fragments in the second half of intron 1, i.e. in the region showing heavy $\mathrm{CG}, \mathrm{CHG}$ and $\mathrm{CHH}$ methylation.

Hence, the VRN-A1 gene is globally devoid of RdDM marks except in regions intimately associated with TErelated sequences. While this type of pattern has been observed at the genome wide level in Arabidopsis [51-55] the detailed gene level characterization of both VRN-A1 methylation pattern and TE annotation makes it a good model to investigate the possible role of such intronic methylation in complex genomes. 


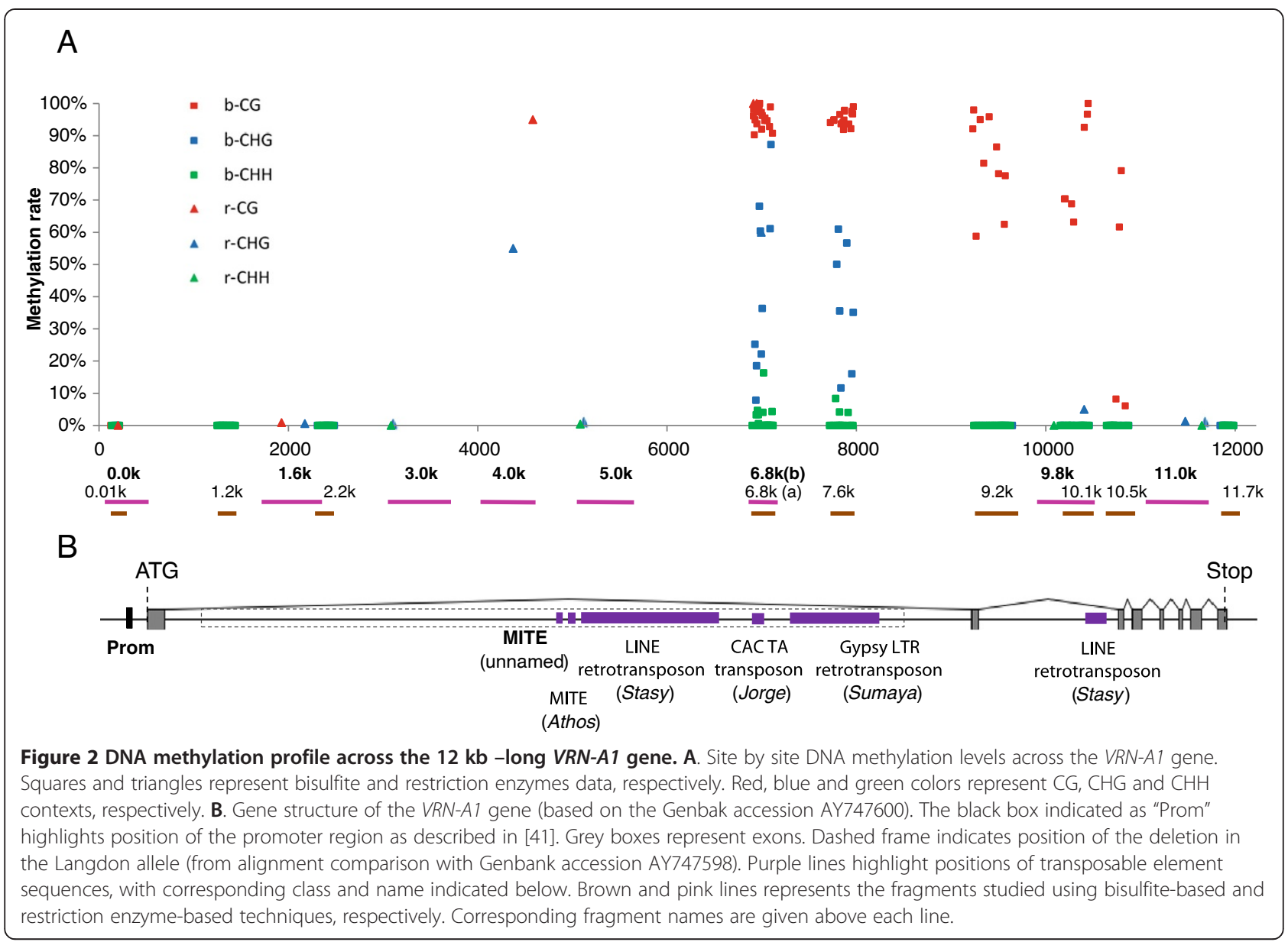

\section{Vernalization hypermethylates VRN-A1 at specific CHG and $\mathrm{CHH}$ sites}

Comparison of the DNA methylation profile of VRN-A1 in vernalized and non-vernalized plants revealed a globally invariable pattern over most of the studied areas. A noticeable exception is the highly methylated area of intron 1, which exhibits a high level of DNA methylation in non-vernalized plants and an even higher methylation level in vernalized plants. This increase does not affect CG sites, which are almost fully methylated in nonvernalized plants and therefore likely saturated. Rather, it occurs at non-CG sites, especially CHG sites and some $\mathrm{CHH}$ sites (Figures 3 and 4).

The observation of a cold-induced hypermethylation at the VRN-A1 gene raises the question of its specificity, that is, whether the hypermethylation observed is a specific response of the VRN-A1 gene, or a consequence of a genome-wide methylation increase at non CG sites following vernalization. Environmental stress is known to induce changes in DNA methylation at the genome-wide level. In particular, a decrease in DNA methylation has been observed at the genomewide level following vernalization in wheat [56]. Cold therefore induces a hypermethylation of VRN-A1 which does not follow the hypomethylation trend observed at the whole genome level as reported in the study of Sherman and Talbert [56]. In this study, V1 vernalization conditions are very close to the conditions used in our study (56 days at $4^{\circ} \mathrm{C}$ followed by one week outside of cold room in [56], compared to 45 days at $4^{\circ} \mathrm{C}$ followed by 10 days in greenhouse in our study), the only difference being the tissue used (apex vs. leaf) and lighting (12 h light vs. 8 hours light). Such a cold-induced genome-wide hypomethylation has also been reported in maize [57], suggesting it is a common response in cereals. Hence, genome-wide hypomethylation also likely applies to our experiment, and points out to a specific regulation of the VRN-A1 gene, or of a limited set of wheat genes/genomic regions.

Similarly, induction of the Asr 1 gene following drought stress in tomato has recently been associated with a change in methylation occurring within its body [58]. Although the changes observed are different (in the Asr 1 case, the stress applied induces a methylation increase at CG sites and a methylation decrease at $\mathrm{CHH}$ sites), these 


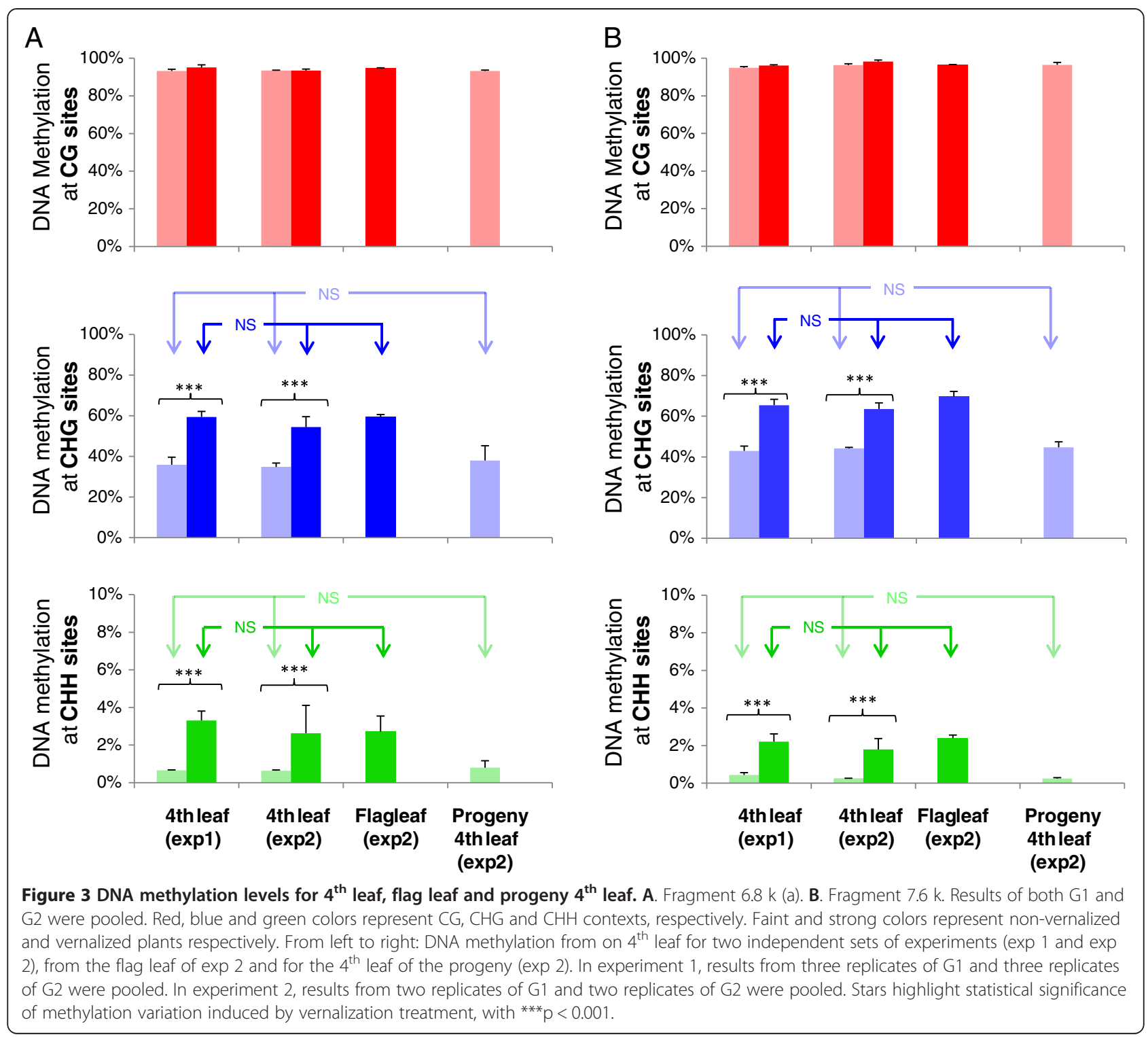

observations suggest that DNA methylation could participate in the regulation of genes involved in specific stress response. Interestingly, while in the Asr 1 case site specificity was difficult to assess due to high methylation levels in control conditions, the methylation increase observed for VRN-A1 is clearly site-specific and restricted to the sites that are already methylated in non-vernalizing conditions. The absence of additional methylated sites suggests a reinforcement of existing methylation signal rather than the establishment of a new methylation signal.

DNA methylation and histone modifications at the promoter The absence of DNA methylation in the promoter of $V R N-A 1$ in both vernalizing and control conditions suggests that the expression change of VRN-A1 does not occur through DNA methylation of its promoter. Both in wheat and barley, previous studies have shown that histone modification at the promoter region is involved in the transcriptional regulation of the VRN1 gene: together with an increase in expression, vernalization treatment induces an increase in the active chromatin mark H3K4me3 and a decrease in the silent mark H3K27me3 in the barley vernalization-responsive variety Sonja [25] and increases H3K4me3 in the Norstar winter wheat cultivar [27]. Combination of these sets of information suggests that the $V R N-A 1$ transcriptional regulation at the promoter would be mediated by histone post-translational modifications rather than DNA methylation. Hence, even though histone post-translational modification and DNA methylation are to some extent interlinked [31,59-62], they could be disconnected in the case of the cold-response regulation of 


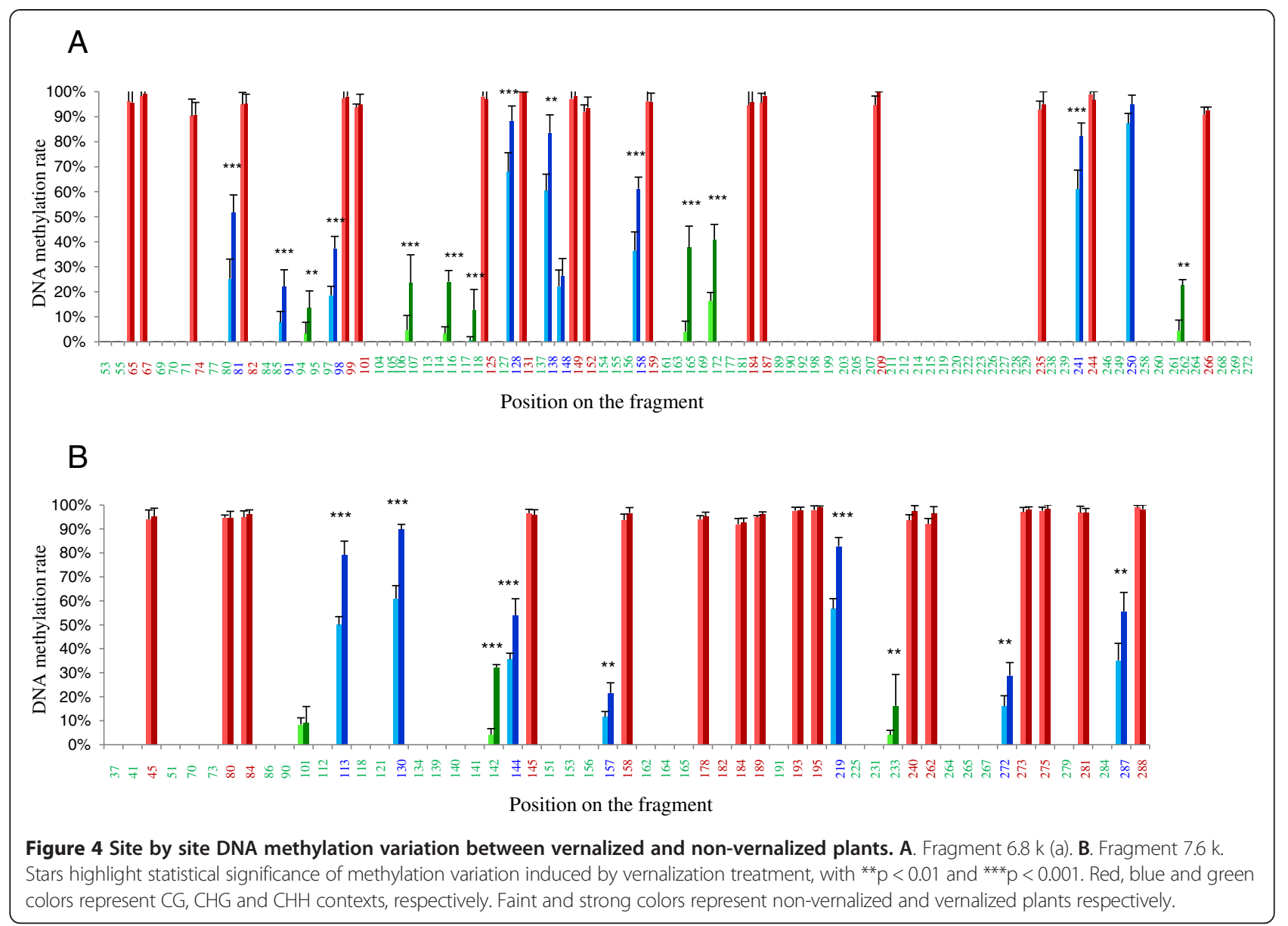

$V R N-A 1$. However, distinction between the three VRN1 homeologous copies is not clear in the Oury-Diallo study [27], thus making it difficult to assess whether the histone mark change observed is occurring at the VRN-A1 gene promoter, at another of the VRN1 gene promoters, or at all VRN1 genes promoters simultaneously. For these reasons, additional studies on both histone marks and DNA methylation need to be performed for this gene on the same plant material, to test for a disconnection between DNA methylation and histone marks.

\section{Methylation of TE fragments in intron 1 does not follow the same trend as other TEs but likely involves the RdDM pathway}

$V R N-A 1$ is body methylated at CG sites, but this methylation profile is not modified by cold treatment. Therefore, although $V R N-A 1$ is body methylated at CG, this body methylation is not associated with the expression change observed between vernalized and non vernalized plants. On the other hand, significant vernalization-induced changes in DNA methylation were found in intron 1 within a region harboring TE fragments, and occurred at $\mathrm{CHG}$ and $\mathrm{CHH}$ sites. Interestingly, TE sequences usually show a decrease in methylation and an increase in expression (and sometimes transposition) following biotic and abiotic stresses $[39,63,64]$. Moreover, TEs were shown to be transcriptionally activated by vernalization treatment in wheat [65]. As transcriptional activation of TEs is usually associated with

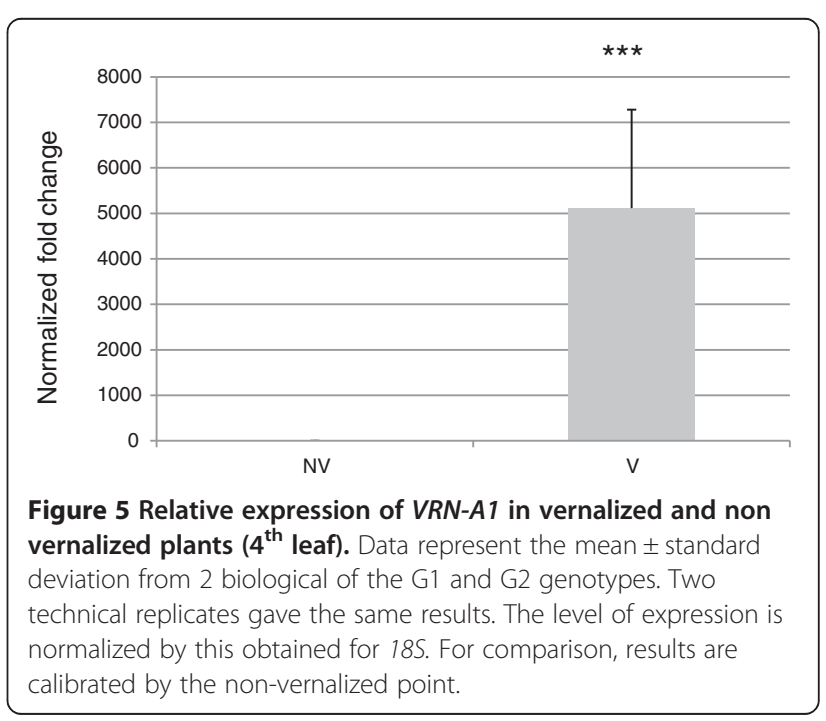




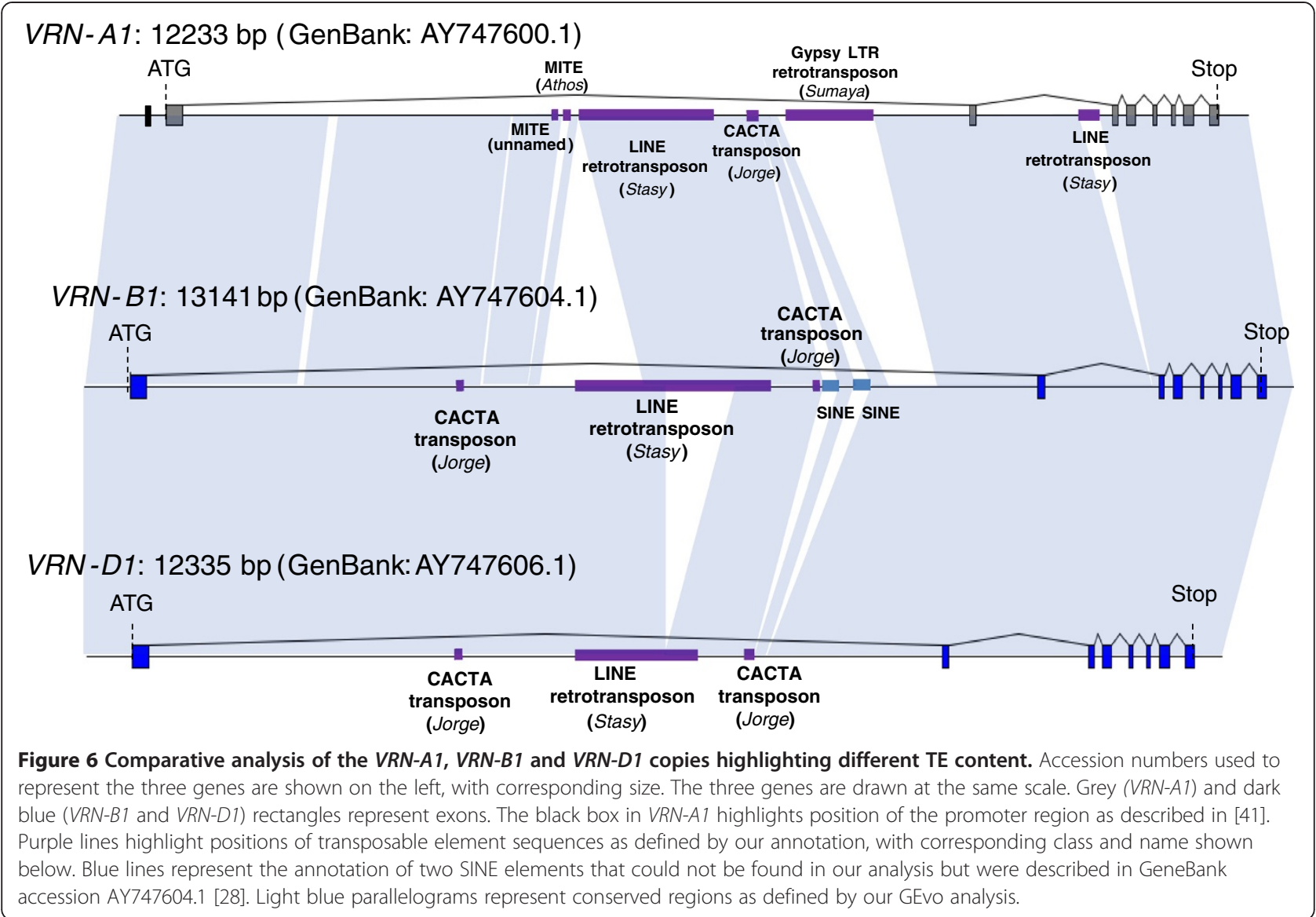

a release of their silencing, our observation that the two TE fragments are hypermethylated following cold treatment suggests they are regulated by a different process.

The observation that hypermethylation occurs at cytosines from $\mathrm{CHG}$ and $\mathrm{CHH}$ contexts points out that the RNA-directed DNA Methylation (RdDM) pathway is likely involved in the hypermethylation process. Interestingly, hypermethylation is restricted to regions bearing TE fragments and targets specific $\mathrm{CHG}$ and $\mathrm{CHH}$ sites that show some methylation in non vernalizing conditions. This suggests that TE fragments could act as facilitators of DNA methylation recruitment [66]: presence of TE fragments would trigger recruitment of the RdDM machinery in control conditions, and this pathway would be even more active following cold conditions. However, because RdDM requires multiple forms of RNA polymerase activity (polymerase IV (polIV), polymerase V (polV), but also polymerase II (polII) itself $[67,68]$ ), additional investigation is required to establish whether the cold-induced methylation occurs through a higher level of PolIV/PolV transcription at TE fragments, or due to a higher PolII transcription of the gene.

While Jorge is a very abundant family that is estimated to harbor hundred thousands of copies in the wheat genome sharing over $90 \%$ identity with their consensus sequence (F. Choulet, pers. comm.), the fragment located on $V R N-A 1$ shares at most $76 \%$ identity with other Jorge copies (from the chromosome $3 \mathrm{~B}$ ) and is likely derived from an old insertion event. The Sumaya family is a middle repetitive element with less than 1000 copies in the wheat genome (F. Choulet, pers. comm.), and these copies share only $75 \%$ with their consensus, suggesting that this family did not amplify recently. The fragment of Sumaya LTR found in VRN-A1 shares at most $81 \%$ identity with another Sumaya copy, and is therefore also an ancient insertion. Because both insertions are old and degenerated, occurrence of the RdDM pathway on these elements could be disconnected from this of the other members of these TE families.

Comparative analysis of the two TE fragments where hypermethylation occurs revealed that the Jorge-like transposon is conserved among the three VRN1 copies, while the Sumaya-like LTR retrotransposon fragment is specific to VRN-A1 (Figure 6). Both elements are conserved between $T$. aestivum A genome and T. monococcum which diverged less than 1.5 My ago [69]. This suggests they could be selectively maintained, and opens the possibility that this TE-related hypermethylation 
might play a role in the regulation of the gene, or in another unknown process.

\section{Methylation of intron 1 and gene expression}

We describe the first case of a mitotically stable increase in DNA methylation in a gene intron, which is reset in the following generation. However, it remains unclear whether the changes in DNA methylation observed are a consequence of the high VRN-A1 expression level induced by cold or if DNA methylation might play an active role in setting $V R N-A 1$ expression levels following cold treatment.

Several studies in wheat and barley support a functional role of promoter histone modification in setting VRN1 expression in the triticea [25-27,70]. But deletion of $V R N-1$ intron 1 is sufficient to induce a spring phenotype [28], thus suggesting a role of this intron in the regulation of $V R N-1$. Although the case of $V R N-A 1$ is not clear in hexaploid wheat (the only variety harboring a deletion within $V R N-A 1$ intron 1 also harbors a deletion of $V R N-D 1$ intron 1), the observation that deletion of part of $V R N-A 1$ intron 1 induces a spring phenotype in tetraploid wheat Triticum turgidum (Langdon cultivar) supports the importance of this intron for the regulation of the $V R N-A 1$ response to cold [28]. The recent expression comparison of $V R N-A 1$ expression in nearisogenic lines of wheat carrying different alleles of the gene clarified that the promoter insertion allele has a larger effect on gene expression than the intron deletion [26]. Altogether, this suggests that histone-based regulation of gene transcription occurring at the promoter is likely explaining most of the expression phenotype observed for $V R N-A 1$. But this does not rule out the possibility of redundant switches in which intron 1 could participate in the regulation of the gene, with a lesser extent.

Oliver et al. [26] also report that the Langdon allele (Genbank accession AY747598), while still inducible by cold, has a 10 fold higher basal expression level than the wild type Triple Dirk allele (Genbank accession AY747600). Interestingly, alignment comparison of these two allele sequences reveals that deletion in the Langdon allele extends from nucleotide 1082 to nucleotide 8253 on the wild type Triple Dirk allele, thus including fragments $6.8 \mathrm{k}$ and $7.6 \mathrm{k}$ (data not shown). Hence, while not critical for the low-temperature response, the hypermethylated region observed could play a role in the regulation of the VRN-A1 gene. But what role?

Recently, methylation at $\mathrm{CHHs}$ in the close vicinity of genes was shown to positively correlate with gene expression in maize, suggesting that this methylation mark may be interlinked with gene expression [42]. In Arabidopsis, DNA methylation at CG and CHG sites in the large IBM1 intron was shown to positively correlate with accumulation of the long transcriptional form of the gene, thus suggesting that intronic DNA methylation at CG and CHG sites may be required for proper IBM1-L transcript elongation [71].

DNA methylation was proposed to prevent spurious expression from cryptic intragenic promoters [36,72] or enhance accurate splicing of primary transcripts [73-75]. Interestingly, analysis of genes with long introns in Arabidopsis revealed that those harboring CHG methylation also tend to have TE insertions [76]. The IBM2 protein, which is enriched at intronic TEs and which mutation affects transcription of genes with long, TE-rich introns, was proposed to avoid premature transcription termination around heterochromatic domains by suppressing antisense transcription from cryptic promoters [76]. Presence of TE fragments may indeed increase the potential for cryptic transcripts, and the hypermethylation observed in VRN-A1 intron could be involved in the taming of such transcripts. Because intron 1 is $8.5 \mathrm{~kb}$ long, its splicing may also be more challenging to accurately complete than the one of smaller introns. Could the inducible hypermethylation observed in TE fragments of intron 1 be associated with its splicing? In honeybee, DNA methylation in exon was shown to be positively associated with retention [77,78]. In plants, a recent study demonstrated that the novel pre-mRNA splicing factor ZOP1 is involved in both pre-mRNA splicing and the RdDM pathway in Arabidopsis and proposed that the splicing machinery may be involved in promoting RdDM and transcriptional silencing. A recent study indicated that inclusion of introns in transgenes can increase the transcripts levels of the transgenes in Arabidopsis [79], suggesting a possible role of the splicing machinery in the regulation of RNA transcript levels. Altogether, these studies suggest that the interconnection between DNA methylation, pre-mRNA splicing and transcripts levels may be more complex than previously anticipated. Further characterization of how the DNA methylation pattern observed impacts the splicing of $V R N-A 1$ intron 1 will likely help better understand this interconnection.

In the Langdon allele, the $7.2 \mathrm{~kb}$ deletion reduces intron size and deletes TE fragments, thus reducing both intron size (therefore likely facilitating splicing) and probability for cryptic promoters. Does the cold-induced hypermethylation observed reduce the impact of splicing and cryptic transcription effects?

TE fragments are remnants that are not able to move, therefore their silencing is not critical to avoid transposition. However, presence of such fragments within introns both enlarge their size (thus likely challenging splicing) and enhance chances for the emergence of cryptic promoters (thus challenging proper transcription). While additional studies are needed to further investigate the role of non CG methylation in introns, our 
study raises the following question: is de novo DNA methylation at intronic TE fragments a remaining trace of original TE silencing, or is it involved in decreasing TE-derived transcriptional effects?

\section{Conclusions}

Our study reveals that vernalization induces hypermethylation of $V R N-A 1$ at specific non CG sites located in TE fragments of large intron 1 , which is associated with gene expression. While additional analyses are needed to investigate whether this hypermethylation is a by-product of gene expression or participates to its regulation, even to a low extent, our study provides the first detailed DNA methylation characterization of $V R N-A 1$. Observation of a cold-induced DNA methylation shift in two winter genotypes following mild vernalization treatment opens the way to examining this DNA methylation pattern in a broader set of vernalization conditions and using more time points (to get insights onto the temporal dynamics of this methylation pattern), as well as in multiple genotypes (to search for other epialleles), thus providing a starting point to investigate the biological role of DNA methylation in the wheat vernalization response. Our findings on $V R N-A 1$ also open interesting questions on the role of intronic $\mathrm{CHH}$ methylation, in particular those which are large and contain TE fragments. In particular, whether the hypermethylation observed in $V R N-A 1$ is also found in $V R N-1 B$ and $V R N-1 D$ copies remains to be elucidated. If a similar hypermethylation is found in all three copies, investigation of the connection of this hypermethylation to presence of other TEs in the B and D copies will help get insights into the underlying mechanism.

\section{Methods}

\section{Plant material}

The plant material was chosen from the wheat genetic resources built in the Dynamic Management Program headed by I. Goldringer, which have been previously characterized for VRN1 allelic diversity [80]. In these populations, as well as in a core collection of 235 accessions [81], four polymorphic sites within the homeologous $V R N 1$ genes (two in $V R N-A 1$, one in $V R N-B 1$ and one in $V R N-D 1$ ) were found associated to earliness per se and vernalization requirement. At each locus, the spring form is dominant over the winter form, as well as over the other loci (epistasis), with variable degree of dominance. Among the 18 haplotypes (i.e., allele combination at the four sites) observed in these two studies, only three (namely $h 3, h 11$ and h14) corresponded mostly to winter phenotypes. On the basis of genotypic and phenotypic data on earliness, two unrelated genotypes of the most frequent winter haplotype (h3), M91.16 and M86.04, were selected. They are referred hereafter as $\mathrm{G} 1$ and $\mathrm{G} 2$, respectively.

\section{Vernalization treatment}

To compare the effect of vernalizing and non-vernalizing treatments, plants were sown in two sets, as presented in Figure 1. For vernalized plants, 3 biological replicates of each genotype were sown in pots in greenhouse conditions $\left(20^{\circ} \mathrm{C}\right.$, with photoperiod of 8 hours light/16 hours dark) for ten days then transferred to a vernalization chamber $\left(4^{\circ} \mathrm{C}\right.$, with photoperiod of 8 hours light/16 hour dark) for 45 days. After 45 days (55 days from sowing, 3 leaves stage), plants were transferred back to the greenhouse for 10 additional days, allowing the growth of the fourth leaf in non-vernalizing conditions. The control set (non-vernalized plants) was sown and kept in greenhouse conditions for 25 days. It was sown 15 days before the end of the vernalizing treatment applied to the first set, so that both sets were synchronized at the same developmental stage for leaf sampling. When fully developed, the 4th leaf of both sets was sampled and subsequently used for DNA and RNA extractions. The same protocol was repeated twice (2 sets of plants with 3 biological replicates each) except that in the second experiment, plants were grown up to the reproductive stage and vernalized plants were selfed to produce progeny, and therefore a 12 hours photoperiod was applied on all plants after vernalization. Progenies of these plants were grown until $4^{\text {th }}$ leaf stage in greenhouse conditions (16 hours light/8 hours night photoperiod). In this second experiment, DNA and RNA were extracted from the $4^{\text {th }}$ leaf and the flag leaf in parental plants and from the $4^{\text {th }}$ leaf in the progeny. The flag leaf was sampled 100 days after sowing (vernalized plants) and $4^{\text {th }}$ leaf of progeny was sampled 34 days after sowing (non vernalized plants).

\section{DNA and RNA extraction}

DNA and RNA extractions were performed on plant tissue collected from one single leaf (4th leaf or flag leaf). DNA was extracted using DNA adsorption on Whatman Unifilter plates by following a protocol derived from the DNeasy 96 Plant kit (QIAGEN, Valencia, CA, USA). Total RNA was extracted using the TRIzol Reagent procedure (Invitrogen). Subsequent DNase treatment and DNase inactivation were carried out according to the instructions of the supplier (Ambion).

\section{Bisulfite analysis using direct sequencing of the converted amplified products}

Sodium bisulfite treatment of genomic DNA was performed using the "EZ DNA Methylation-Gold" kit (Zymo Research), following manufacturer's protocol. Around $350 \mathrm{ng}$ of DNA were used as input for bisulfite treatment, and $2 \mu \mathrm{l}$ of the $10 \mu$ l eluted solutions were used for each PCR reaction. Bisulfite PCR primers were designed for the plus strand, using the Methyl Primer Express v.1.0 software (Applied Biosystems). Primer design was based on the TripleDirkC sequence (Genbank 
accession AY747600) and is detailed in Additional file 1. Primer pairs amplifying the 9 analyzed fragments are listed in Table 1. For fragments $6.8 \mathrm{k}$ and $7.6 \mathrm{k}$, which overlap with repetitive sequences, search for possible cross-amplification was performed by aligning sequences of these amplicons to available wheat shotgun sequences, using BLASTN searches (http://wheat-urgi.versailles.inra. $\mathrm{fr} /$ Seq-Repository/BLAST) on the IWGSC wheat shotgun sequences (http://www.wheatgenome.org/). These searches revealed that these two amplicons share only $89 \%$ nucleotide identity with the closest wheat genomic sequence found. Careful analysis of sequencing traces was also performed in order to check for presence of possible multiple peaks, which should be observed in the case of crossamplification with repetitive sequences diverging for some SNPs. Such double-peaks were never observed, thus validating sequence-specific amplification.

PCR reactions were performed in a final volume of $50 \mu \mathrm{l}$ containing $2 \mu \mathrm{l}$ bisulfite-treated DNA, 1X buffer (Roche ${ }^{\circ}$ ) at $2 \mathrm{mM} \mathrm{MgCl}_{2}, 0.25 \mathrm{Mm} \mathrm{dNTP}, 0.4 \mu \mathrm{M}$ of forward and reverse primers, and 2.5 Units of hotstart Taq DNA polymerase (FastStart, Roche) using the following PCR program: an initial denaturation step $\left(95^{\circ} \mathrm{C}, 6 \mathrm{~min}\right)$ was followed by 20 touch-down cycles $\left(10\right.$ cycles of $94^{\circ} \mathrm{C}$, $1 \mathrm{~min} ; 65^{\circ} \mathrm{C}$ to $55^{\circ} \mathrm{C}, 1 \mathrm{~min}, 1^{\circ} \mathrm{C}$ decrease after each cycle; $72^{\circ} \mathrm{C}, 1 \mathrm{~min} 30 \mathrm{sec}$ followed by 10 additional cycles of: $94^{\circ} \mathrm{C}, 1 \mathrm{~min} ; 55^{\circ} \mathrm{C}$ to $50^{\circ} \mathrm{C}, 1 \mathrm{~min}, 0.5^{\circ} \mathrm{C}$ decrease after each cycle; $\left.72^{\circ} \mathrm{C}, 1 \mathrm{~min} 30 \mathrm{sec}\right)$ and 20 final cycles $\left(94^{\circ} \mathrm{C}\right.$ $45 \mathrm{sec} ; 50^{\circ} \mathrm{C}, 45 \mathrm{sec} ; 72^{\circ} \mathrm{C}, 1 \mathrm{~min}$ ), with a final elongation step $\left(72^{\circ} \mathrm{C}, 7 \mathrm{~min}\right)$. Size, quality and quantity of the PCR products were checked using $2 \%$ agarose gel electrophoresis. Direct Sanger sequencing of the PCR products was performed using the same primers used for PCR, without cloning. Chromatograms were analyzed for methylation quantification using the Mutation Surveyor Software (SOFTGE$\mathrm{NETICS}^{\odot}$ ) with default parameters. For the validation of direct bisulfite sequencing method, two PCR products used for direct sequencing were also cloned and Sanger sequenced. Cloning was performed using the $\mathrm{pGEM}^{\ominus}-\mathrm{T}$ vector system (Promega), following manufacturer's protocol. Twenty clones per sample were sequenced using M13 forward and reverse primers and $\mathrm{C} / \mathrm{T}$ polymorphisms among clones were visualized using the Kismeth [82].

\section{Restriction analysis and methyl-sensitive PCR semi-quantitative amplification}

To validate the bisulfite results and to further investigate the DNA methylation pattern of regions reluctant to the bisulfite procedure, three restriction enzymes (Bst $\mathrm{UI}$, MspI and PspGI, Table 2) were used. A-genome specific primer pairs were designed to amplify 8 fragments spanning the $V R N-A 1$ gene sequence, each containing at least one restriction site for at least one of the above mentioned restriction enzymes (for details, see Table 3).
For each enzymatic reaction, $100 \mathrm{ng}$ of genomic DNA (from vernalized and non-vernalized plants) were incubated with $10 \mathrm{U}$ enzyme in a final volume of $20 \mu \mathrm{l}$, in the following conditions: $16 \mathrm{hr}$ at $37^{\circ} \mathrm{C}$ for $\mathrm{MspI}, 2$ hours at $60^{\circ} \mathrm{C}$ for $B s t \mathrm{UI}$, or 1 hour at $75^{\circ} \mathrm{C}$ for PspGI. After each enzymatic reaction, cleavage efficiency was assessed for the different regions (primer pairs listed in Table 3) through semi-quantitative PCR, using digested DNA and genomic DNA from vernalized and non-vernalized plants as matrix. PCR reactions were performed in $30 \mu \mathrm{l}$ with 1X Go Taq buffer, $1.5 \mathrm{mM} \mathrm{MgCl}_{2}, 0.25 \mathrm{mM} \mathrm{dNTP}$, 1X Q-solution (QIAGEN), $0.5 \mu \mathrm{M}$ of forward and reverse primers, $2 \mu \mathrm{l}$ of GoTaq polymerase (Promega) and 10 ng digested DNA using the following PCR program: initial denaturation step $\left(94^{\circ} \mathrm{C}, 4 \mathrm{~min}\right)$ followed by 10 touch-down cycles (denaturation: $94^{\circ} \mathrm{C}, 1 \mathrm{~min}$; annealing: $68^{\circ} \mathrm{C}-60^{\circ} \mathrm{C}, 1 \mathrm{~min}, 1^{\circ} \mathrm{C}$ decrease after each cycle; elongation: $72^{\circ} \mathrm{C}, 1.30 \mathrm{~min}$ ) followed by 18 to 30 cycles $\left(94^{\circ} \mathrm{C}, 45 \mathrm{sec} ; 60^{\circ} \mathrm{C}, 45 \mathrm{sec} ; 72^{\circ} \mathrm{C}, 1 \mathrm{~min}\right)$, and a final elongation step $\left(72^{\circ} \mathrm{C}, 5 \mathrm{~min}\right)$. Five microliters of each PCR product were loaded on a $2 \%$ agarose gel and amplicon quantity was estimated using the ImageJ software [83]. Details on primer design and number of PCR cycles are described in Additional file 1.

\section{Gene expression analysis using qRT-PCR}

$30 \mu \mathrm{g}$ of total RNA were treated with DNase (Ambion) then reverse transcribed using random hexamers (Invitrogen), 100 units of SuperScript II (Invitrogen) and 40 units of recombinant RNasin Ribonuclease Inhibitor (Promega) in a final volume of $20 \mu \mathrm{L}$.

A-genome specific primers were designed using Primer Express 2.0 (Applied Biosystem) with an amplicon size criterion of $150 \mathrm{bp}$ and an annealing temperature of $60^{\circ} \mathrm{C}$. Quantitative PCR was performed in a $25 \mu$ l total volume, with a final concentration of $300 \mathrm{nM}$ of each primer. Quantitative PCR was performed using the 7500 ABI quantitative PCR system (Applied Biosystem) with Sybr-Green ${ }^{\circledast}$ as fluorophore and under the following conditions: 40 cycles of denaturation $\left(95^{\circ} \mathrm{C}, 10 \mathrm{sec}\right)$, annealing/elongation $\left(60^{\circ} \mathrm{C}, 60 \mathrm{sec}\right)$. Melting curve was made from 60 to $95^{\circ} \mathrm{C}$ every $0.5^{\circ} \mathrm{C}$. A calibration step of the experiment was used to check for PCR efficiency. Standard curves (log of cDNA dilution vs. Ct) using serial 10-fold dilution of cDNA were built for each pair of selected primers, a $100 \%$ efficiency corresponding to a slope of -3.3 [84]. Practically, only pairs of primers yielding a slope of $-3.3 \pm 0.1$ were selected. The specificity of the amplification (checked by dissociation curve analysis, gel electrophoresis and sequencing of the PCR product) was also assessed. From these results, one primer pair located within the 3'UTR of the $V R N-A 1$ gene (VRN-A1_3UTR_F: GGGCTGAGATGGCTGTACG, VRNA1_3UTR_R: CAGTAGAGACGGGTATCATGG), and one 
primer pair located within the $18 \mathrm{~S}$ gene (18S_F: GTGACGGGTGACGGAGAATT and 18S R: GACAC TAATGCGCCCGGTAT) were used. Although we tried several primer pairs for several housekeeping genes, only the $18 \mathrm{~S}$ primer pair was giving good efficiency and specificity on our material. The $18 \mathrm{~S}$ gene being a lot more expressed than the VRN-A1 gene in our material, a 1/50 dilution was used as matrix for the VRN-A1 qPCRs, and a 1/100 dilution of this solution was used for the $18 \mathrm{~S}$ qPCRs. qPCR reactions were run by duplicate and one nontemplate negative control was included for each primer pair. All PCR reactions were made in the same plate. For each biological replicate, an average $\mathrm{Ct}$ value was calculated from the two technical replicates. Corresponding $2^{\Delta \mathrm{Ct}}$ were then calculated for each biological replicates, and mean and standard deviation was calculated for the 4 biological replicates ( 2 plants from genotype G1 and 2 plants from genotype G2). Relative expression was calculated by normalizing the results by these obtained for non vernalized plants.

\section{TE annotation in the VRN-A1 winter genotype sequences}

To check for possible presence of transposable elements within the $V R N-A 1$ winter allele, we ran a Repeatmasker analysis [85] with default parameters, using the $V R N-A 1$ sequence of the winter wheat TripleDirkC cultivar (corresponding to Genbank accession AY747600) as query and a wheat transposable elements database obtained from $18 \mathrm{Mb}$ of the $3 \mathrm{~B}$ chromosome sequence [44] as database. For each case of homology, percent identity between the TripleDirkC VRN-A1 sequence and the sequences from the database were also extracted. Note that TripleDirkC and the two studied genotypes (G1 and G2) share the same $V R N-A 1$ haplotype. The same analysis was also performed on VRN-B1 (Genbank accession AY747604) and VRN-D1 (Genbank accession AY747606) genes from Triple DirkC, to check whether the TE described in $V R N-A 1$ were shared in the other two VRN1 homeologous copies. Finally, the three VRN1 sequences were compared using GEvo (http:// genomevolution.org/CoGe/GEvo.pl) using the "BLASTN: small regions" algorithm with standard parameters. Results of this comparison and of the TE annotation were compiled to highlight which of the VRN-A1 TEs are conserved among the three genes and which are specific to VRN-A1.

\section{Statistical analyses of methylation variation}

To test the significance of methylation variation, analysis of variance was performed by using the model $Y_{i j k}=\mu+$ $G_{i}+T_{j}+\varepsilon_{i j k}$ where $G$ represents the genotypic effect, $T$ represents treatment effect (vernalizing vs. nonvernalizing) and $\varepsilon_{i j k}$ the residual. As the $Y_{i j k}$ are percentages, Log, Arcsin or square-root transformations of variables were performed when necessary to improve normality of residuals in the ANOVA.

\section{Additional files}

Additional file 1: Corresponds to supplementary text.

Additional file 2: Corresponds to supplementary figures.

\section{Abbreviations}

FLC: FLOWERING LOCUS C; TE: Transposable element; PCR: Polymerase chain reaction; qPCR: quantitative PCR; RdDM: RNA-directed DNA Methylation; VRN1: Vernalization 1

\section{Competing interests}

The authors declare that they have no competing interest.

\section{Authors' contributions}

ARK performed bisulfite analyses, participated in methylsensitive PCR analyses and drafted part of the manuscript; JE participated in bisulfite, methylsensitive PCR and statistical analyses and coordination, and corrected the manuscript; ACM carried out methylsensitive PCRs and drafted part of the manuscript, AR carried out qRT-PCRs and performed quantitative PCR analyses, IG participated in study design and corrected the manuscript; CV participated in bisulfite and qRT-PCR analyses and coordination, performed transposable element annotations, and drafted and corrected the manuscript. JE and CV conceived and designed the study. All authors read and approved the final manuscript.

\section{Acknowledgements}

The authors thank S. Jouanne and N. Galic for help in plant material growth, C. Remoué for DNA and RNA extractions and cDNA production, M.-P. Jacquemot for help in qRT-PCR setting and analyses, J.M. Casacuberta for technical tips on bisulfite analyses, F. Choulet for providing exemplar wheat TE database, E. Paux for providing DNA to test for primer specificity, and S. Castelletti for help in comparative gene sequence analyses. We are also grateful to V. Colot, K. Dawe, J. Gent and H. Vaucheret for helpful discussions on the results, to S. Maury and M. Mirouze for critical reading of a first version of the manuscript and valuable suggestions to improve it, and to two anonymous reviewers for their valuable comments on the original manuscript. This study has received funding from the European Community's Seventh Framework Programme (FP7/ 2007-2013) under the Grant Agreement n245058-Solibam (Strategies for Organic and Low-input Integrated Breeding and Management). The PhD thesis of A. R. Khan was supported by the Higher Education Commission (HEC) of Pakistan.

\section{Author details}

${ }^{1}$ INRA, UMR de Génétique Végétale, Gif sur Yvette F-91190, France. ${ }^{2}$ CNRS, UMR de Génétique Végétale, Gif sur Yvette F-91190, France.

Received: 1 August 2013 Accepted: 25 November 2013 Published: 11 December 2013

\section{References}

1. Snape JW, Butterworth K, Whitechurch E, Worland AJ: Waiting for fine times: genetics of flowering time in wheat. Euphytica 2001, 119:185-190.

2. Sheldon CC, Rouse DT, Finnegan EJ, Peacock WJ, Dennis ES: The Molecular Basis of Vernalization: The Central Role of FLOWERING LOCUS C (FLC). Proc Natl Acad Sci USA 2000, 97:3753-3758.

3. Sung S, He Y, Eshoo TW, Tamada Y, Johnson L, Nakahigashi K, Goto K, Jacobsen SE, Amasino RM: Epigenetic maintenance of the vernalized state in Arabidopsis thaliana requires LIKE HETEROCHROMATIN PROTEIN 1. Nat Genet 2006, 38:706-710.

4. Trevaskis B, Hemming MN, Dennis ES, Peacock WJ: The molecular basis of vernalization-induced flowering in cereals. Trends Plant Sci 2007, 12:352-357.

5. Trap-Gentil M-V, Hébrard C, Lafon-Placette C, Delaunay A, Hagège D, Joseph C, Brignolas F, Lefebvre M, Barnes S, Maury S: Time course and amplitude of DNA methylation in the shoot apical meristem are critical points for bolting induction in sugar beet and bolting tolerance between genotypes. J Exp Bot 2011, 62:2585-2597.

6. Allard V, Veisz O, Kõszegi B, Rousset $M$, Gouis JL, Martre P: The quantitative response of wheat vernalization to environmental variables indicates that vernalization is not a response to cold temperature. J Exp Bot 2012, 63:847-857. 
7. Sung S, Amasino RM: Remembering winter: toward a molecular understanding of vernalization. Annu Rev Plant Biol 2005, 56:491-508.

8. Bastow R, Mylne JS, Lister C, Lippman Z, Martienssen RA, Dean C: Vernalization requires epigenetic silencing of FLC by histone methylation. Nature 2004, 427:164-167.

9. Sung S, Amasino RM: Vernalization in Arabidopsis thaliana is mediated by the PHD finger protein VIN3. Nature 2004, 427:159-164.

10. Finnegan EJ, Dennis ES: Vernalization-induced trimethylation of histone $\mathrm{H} 3$ lysine 27 at FLC is not maintained in mitotically quiescent cells. Curr Biol 2007, 17:1978-1983.

11. Sheldon CC, Hills MJ, Lister C, Dean C, Dennis ES, Peacock WJ: Resetting of FLOWERING LOCUS C expression after epigenetic repression by vernalization. Proc Natl Acad Sci USA 2008, 105:2214-2219.

12. Trevaskis B, Bagnall DJ, Ellis MH, Peacock WJ, Dennis ES: MADS box genes control vernalization-induced flowering in cereals. Proc Natl Acad SCl USA 2003, 100:13099-13104.

13. Yan L, Loukoianov A, Tranquilli G, Helguera M, Fahima T, Dubcovsky J: Positional cloning of the wheat vernalization gene VRN1. Proc Natl Acad Sci USA 2003, 100:6263-6268.

14. Danyluk J, Kane N, Breton G, Limin A, Fowler D, Sarhan F: TaVRT-1, a putative transcription factor associated with vegetative to reproductive transition in cereals. Plant Physiol 2003, 132:1849-1860.

15. Murai K, Miyamae M, Kato H, Takumi S, Ogihara Y: WAP1, a Wheat APETALA1 Homolog, Plays a Central Role in the Phase Transition from Vegetative to Reproductive Growth. Plant Cell Physiol 2003, 44:1255-1265.

16. Preston JC, Kellogg EA: Reconstructing the Evolutionary History of Paralogous APETALA1/FRUITFULL-Like Genes in Grasses (Poaceae). Genetics 2006, 174:421-437.

17. Shitsukawa N, Ikari C, Shimada S, Kitagawa S, Sakamoto K, Saito H, Ryuto H, Fukunishi N, Abe T, Takumi S, Nasuda S, Murai K: The einkorn wheat (Triticum monococcum) mutant, maintained vegetative phase, is caused by a deletion in the VRN1 gene. Genes Genet Syst 2007, 82:167-170.

18. Trevaskis B: The central role of the VERNALIZATION1 gene in the vernalization response of cereals. Funct Plant Biol 2010, 37:479-487.

19. Trevaskis B, Hemming M, Peacock W, Dennis E: HvVRN2 responds to daylength, whereas HvVRN1 is regulated by vernalization and developmental status. Plant Physiol 2006, 140:1397-1405.

20. Zhang $X$, Yazaki J, Sundaresan A, Cokus S, Chan SW-L, Chen H, Henderson IR, Shinn P, Pellegrini M, Jacobsen SE, Ecker JR: Genome-wide HighResolution Mapping and Functional Analysis of DNA Methylation in Arabidopsis. Cell 2006, 126:1189-1201.

21. Hemming MN, Peacock WJ, Dennis ES, Trevaskis B: Low-Temperature and Daylength Cues Are Integrated to Regulate FLOWERING LOCUS T in Barley. Plant Physiol 2008, 147:355-366.

22. Chen A, Dubcovsky J: Wheat TILLING Mutants Show That the Vernalization Gene VRN1 Down-Regulates the Flowering Repressor VRN2 in Leaves but Is Not Essential for Flowering. PLoS Genet 2012, 8:e1003134.

23. Loukoianov A, Yan L, Blechl A, Sanchez A, Dubcovsky J: Regulation of VRN-1 Vernalization Genes in Normal and Transgenic Polyploid Wheat. Plant Physiol 2005, 138:2364-2373.

24. Sasani S, Hemming M, Oliver S, Greenup A, Tavakkol-Afshari R, Mahfoozi S, Poustini K, Sharifi H, Dennis E, Peacock W, Trevaskis B: The influence of vernalization and daylength on expression of flowering-time genes in the shoot apex and leaves of barley (Hordeum vulgare). J Exp Bot 2009, 60:2169-2178.

25. Oliver SN, Finnegan EJ, Dennis ES, Peacock WJ, Trevaskis B: Vernalizationinduced flowering in cereals is associated with changes in histone methylation at the VERNALIZATION1 gene. Proc Natl Acad Sci USA 2009, 106:8386-8391.

26. Oliver SN, Deng W, Casao MC, Trevaskis B: Low temperatures induce rapid changes in chromatin state and transcript levels of the cereal VERNALIZATION1 gene. J Exp Bot 2013, 64:2413-2422.

27. Diallo AO, Ali-Benali MA, Badawi M, Houde M, Sarhan F: Expression of vernalization responsive genes in wheat is associated with histone $\mathrm{H} 3$ trimethylation. Mol Genet Genomics 2012, 287:575-590.

28. Fu D, Szucs P, Yan L, Helguera M, Skinner JS, von Zitzewitz J, Hayes PM, Dubcovsky $\mathrm{J}$ : Large deletions within the first intron in VRN-1 are associated with spring growth habit in barley and wheat. Mol Genet Genomics 2005, 273:54-65.

29. Finnegan JE, Kovac KA, Jaligot E, Sheldon CC, James Peacock W, Dennis ES: The downregulation of FLOWERING LOCUS C (FLC) expression in plants with low levels of DNA methylation and by vernalization occurs by distinct mechanisms. Plant J 2005, 44:420-432.
30. Zhang M, Kimatu JN, Xu K, Liu B: DNA cytosine methylation in plant development. J Genet Genomics 2010, 37:1-12.

31. Law JA, Jacobsen SE: Establishing, maintaining and modifying DNA methylation patterns in plants and animals. Nature Rev Genetics 2010, 11:204-220.

32. Weigel D, Colot V: Epialleles in plant evolution. Genome Biol 2012, 13:249.

33. Zhang $Y-Y$, Fischer $M$, Colot $V$, Bossdorf $O$ : Epigenetic variation creates potential for evolution of plant phenotypic plasticity. New Phytol 2013, 197:314-322.

34. Feng S, Cokus SJ, Zhang X, Chen P-Y, Bostick M, Goll MG, Hetzel J, Jain J, Strauss SH, Halpern ME, Ukomadu C, Sadler KC, Pradhan S, Pellegrini M, Jacobsen SE: Conservation and divergence of methylation patterning in plants and animals. Proc Natl Acad Sci USA 2010, 107:8689-8694.

35. Zemach A, McDaniel IE, Silva P, Zilberman D: Genome-Wide Evolutionary Analysis of Eukaryotic DNA Methylation. Science 2010, 328:916-919.

36. Zilberman D, Gehring M, Tran RK, Ballinger T, Henikoff S: Genome-wide analysis of Arabidopsis thaliana DNA methylation uncovers an interdependence between methylation and transcription. Nat Genetics 2006, 39:61-69.

37. Lister R, O'Malley RC, Tonti-Filippini J, Gregory BD, Berry CC, Millar AH, Ecker JR: Highly Integrated Single-Base Resolution Maps of the Epigenome in Arabidopsis. Cell 2008, 133:523-536.

38. Cokus SJ, Feng S, Zhang X, Chen Z, Merriman B, Haudenschild CD, Pradhan S, Nelson SF, Pellegrini M, Jacobsen SE: Shotgun bisulphite sequencing of the Arabidopsis genome reveals DNA methylation patterning. Nature 2008, 452:215-219.

39. Dowen RH, Pelizzola M, Schmitz RJ, Lister R, Dowen JM, Nery JR, Dixon JE, Ecker JR: Widespread dynamic DNA methylation in response to biotic stress. Proc Natl Acad Sci USA 2012, 109:E2183-E2191.

40. Yu A, Lepère $G$, Jay F, Wang J, Bapaume L, Wang Y, Abraham A-L, Penterman J, Fischer RL, Voinnet O, Navarro L: Dynamics and biological relevance of DNA demethylation in Arabidopsis antibacterial defense. Proc Natl Acad Sci USA 2013, 110:2389-2394.

41. Yan L, Helguera M, Kato K, Fukuyama S, Sherman J, Dubcovsky J: Allelic variation at the VRN-1 promoter region in polyploid wheat. Theor Appl Genet 2004, 109:1677-1686.

42. Gent Jl, Ellis NA, Guo L, Harkess AE, Yao Y, Zhang X, Dawe RK: CHH islands: de novo DNA methylation in near-gene chromatin regulation in maize. Genome Res 2013, 23:628-637.

43. Regulski M, Lu Z, Kendall J, Donoghue MTA, Reinders J, Llaca V, Deschamps S, Smith A, Levy D, McCombie WR, Tingey S, Rafalski A, Hicks J, Ware D, Martienssen R: The maize methylome influences mRNA splice sites and reveals widespread paramutation-like switches guided by small RNA. Genome Res 2013, 23:1651-1662.

44. Choulet F, Wicker T, Rustenholz C, Paux E, Salse J, Leroy P, Schlub S, Paslier M-CL, Magdelenat G, Gonthier C, Couloux A, Budak H, Breen J, Pumphrey M, Liu S, Kong X, Jia J, Gut M, Brunel D, Anderson JA, Gill BS, Appels R, Keller B, Feuillet C: Megabase Level Sequencing Reveals Contrasted Organization and Evolution Patterns of the Wheat Gene and Transposable Element Spaces. Plant Cell 2010, 22:1686-1701.

45. Takuno S, Gaut BS: Body-Methylated Genes in Arabidopsis thaliana Are Functionally Important and Evolve Slowly. Mol Biol Evol 2012, 29:219-227.

46. Zubko E, Gentry M, Kunova A, Meyer P: De novo DNA methylation activity of methyltransferase 1 (MET1) partially restores body methylation in Arabidopsis thaliana. Plant J 2012, 71:1029-1037.

47. Kakutani T, Kato M, Kinoshita T, Miura A: Control of development and transposon movement by DNA methylation in Arabidopsis thaliana. Cold Spring Harb Symp Quant Biol 2004, 69:139-143.

48. Slotkin RK, Martienssen R: Transposable elements and the epigenetic regulation of the genome. Nat Rev Genetics 2007, 8:272-285.

49. Lisch D: Epigenetic regulation of transposable elements in plants. Annu Rev Plant Biol 2009, 60:43-66.

50. Bucher E, Reinders J, Mirouze M: Epigenetic control of transposon transcription and mobility in Arabidopsis. Curr Opin Plant Biol 2012, 15:503-510.

51. Chan SW-L, Zhang X, Bernatavichute YV, Jacobsen SE: Two-Step Recruitment of RNA-Directed DNA Methylation to Tandem Repeats. PLOS Bio 2006, 4:e363.

52. Weil C, Martienssen R: Epigenetic interactions between transposons and genes: lessons from plants. Curr Opin Genet Dev 2008, 18:188-192.

53. Henderson IR, Jacobsen SE: Tandem repeats upstream of the Arabidopsis endogene SDC recruit non-CG DNA methylation and initiate siRNA spreading. Genes Dev 2008, 22:1597-1606.

54. Saze $H$, Kakutani T: Differentiation of epigenetic modifications between transposons and genes. Curr Opin Plant Biol 2011, 14:81-87. 
55. Wierzbicki AT, Cocklin R, Mayampurath A, Lister R, Rowley MJ, Gregory BD, Ecker JR, Tang H, Pikaard CS: Spatial and functional relationships among Pol V-associated loci, Pol IV-dependent siRNAs, and cytosine methylation in the Arabidopsis epigenome. Genes Dev 2012, 26:1825-1836.

56. Sherman J, Talbert L: Vernalization-induced changes of the DNA methylation pattern in winter wheat. Genome 2002, 45:253-260.

57. Shan X, Wang X, Yang G, Wu Y, Su S, Li S, Liu H, Yuan Y: Analysis of the DNA methylation of maize (Zea mays L.) in response to cold stress based on methylation-sensitive amplified polymorphisms. J Plant Biol 2013, 56:32-38.

58. González RM, Ricardi MM, lusem ND: Atypical epigenetic mark in an atypical location: cytosine methylation at asymmetric (CNN) sites within the body of a non-repetitive tomato gene. BMC Plant Biol 2011, 11:94.

59. Tamaru H, Selker EU: A histone H3 methyltransferase controls DNA methylation in Neurospora crassa. Nature 2001, 414:277-283.

60. Tariq M, Saze H, Probst A, Lichota J, Habu Y, Paszkowski J: Erasure of CpG methylation in Arabidopsis alters patterns of histone $\mathrm{H} 3$ methylation in heterochromatin. Proc Natl Acad Sci USA 2003, 100:8823-8827.

61. Li X, Wang X, He K, Ma Y, Su N, He H, Stolc V, Tongprasit W, Jin W, Jiang J, Terzaghi W, Li S, Deng XW: High-Resolution Mapping of Epigenetic Modifications of the Rice Genome Uncovers Interplay Between DNA Methylation, Histone Methylation, and Gene Expression. Plant Cell 2008, 20:259-276.

62. Cedar $\mathrm{H}$, Bergman $\mathrm{Y}$ : Linking DNA methylation and histone modification: patterns and paradigms. Nat Rev Genet 2009, 10:295-304.

63. Grandbastien M-A, Audeon C, Bonnivard E, Casacuberta JM, Chalhoub B, Costa A-PP, Le QH, Melayah D, Petit M, Poncet C, Tam SM, van Sluys M-A, Mhiri C: Stress activation and genomic impact of Tnt1 retrotransposons in Solanaceae. Cytogenet Genome Res 2005, 110:229-241.

64. Zeller G, Henz SR, Widmer CK, Sachsenberg T, Rätsch G, Weigel D, Laubinger S: Stress induced changes in the Arabidopsis thaliana transcriptome analyzed using whole genome tiling arrays. Plant J 2009, 58:1068-1082.

65. Laudencia-Chingcuanco D, Fowler DB: Genotype-dependent Burst of Transposable Element Expression in Crowns of Hexaploid Wheat (Triticum aestivum L.) during Cold Acclimation. Comp Funct Genomics 2012, 2012:1-9.

66. Richards EJ: Inherited epigenetic variation-revisiting soft inheritance. Nat Rev Genet 2006, 7:395-401.

67. Zheng B, Wang Z, Li S, Yu B, Liu J-Y, Chen X: Intergenic transcription by RNA polymerase II coordinates Pol IV and Pol V in siRNA-directed transcriptional gene silencing in Arabidopsis. Genes Dev 2009, 23:2850-2860.

68. Haag JR, Pikaard CS: Multisubunit RNA polymerases IV and V: purveyors of non-coding RNA for plant gene silencing. Nat Rev Mol Cell Biol 2011, 12:483-492.

69. Matsuoka Y: Evolution of Polyploid Triticum Wheats under Cultivation: The Role of Domestication, Natural Hybridization and Allopolyploid Speciation in their Diversification. Plant Cell Physiol 2011, 52:750-764

70. Alonso-Peral MM, Oliver SN, Casao MC, Greenup AA, Trevaskis B: The Promoter of the Cereal VERNALIZATION1 Gene Is Sufficient for Transcriptional Induction by Prolonged Cold. PLOS ONE 2011, 6:e29456.

71. Rigal M, Kevei Z, Pélissier T, Mathieu O: DNA methylation in an intron of the IBM1 histone demethylase gene stabilizes chromatin modification patterns. EMBO J 2012, 31:2981-2993.

72. Maunakea AK, Nagarajan RP, Bilenky M, Ballinger TJ, D'Souza C, Fouse SD, Johnson BE, Hong C, Nielsen C, Zhao Y, Turecki G, Delaney A, Varhol R, Thiessen N, Shchors K, Heine VM, Rowitch DH, Xing X, Fiore C, Schillebeeckx M, Jones SJM, Haussler D, Marra MA, Hirst M, Wang T, Costello JF: Conserved role of intragenic DNA methylation in regulating alternative promoters. Nature 2010, 466:253-257.

73. Lorincz MC, Dickerson DR, Schmitt M, Groudine M: Intragenic DNA methylation alters chromatin structure and elongation efficiency in mammalian cells. Nat Struct Mol Biol 2004, 11:1068-1075.

74. Luco RF, Pan Q, Tominaga K, Blencowe BJ, Pereira-Smith OM, Misteli T: Regulation of Alternative Splicing by Histone Modifications. Science 2010, 327:996-1000.

75. Shukla S, Kavak E, Gregory M, Imashimizu M, Shutinoski B, Kashlev M, Oberdoerffer P, Sandberg R, Oberdoerffer S: CTCF-promoted RNA polymerase II pausing links DNA methylation to splicing. Nature 2011, 479:74-79.

76. Saze H, Kitayama J, Takashima K, Miura S, Harukawa Y, Ito T, Kakutani T: Mechanism for full-length RNA processing of Arabidopsis genes containing intragenic heterochromatin. Nature Comm 2013, 4:2301.
77. Flores K, Wolschin F, Corneveaux JJ, Allen AN, Huentelman MJ, Amdam GV: Genome-wide association between DNA methylation and alternative splicing in an invertebrate. BMC Genomics 2012, 13:480.

78. Li-Byarlay H, Li Y, Stroud H, Feng S, Newman TC, Kaneda M, Hou KK, Worley KC, Elsik CG, Wickline SA, Jacobsen SE, Ma J, Robinson GE: RNA interference knockdown of DNA methyl-transferase 3 affects gene alternative splicing in the honey bee. PNAS 2013, 110:12750-12755.

79. Christie $M$, Croft $L J$, Carroll BJ: Intron splicing suppresses RNA silencing in Arabidopsis. Plant J 2011, 68:159-167

80. Rhone B, Remoue C, Galic N, Goldringer I, Bonnin I: Insight into the genetic bases of climatic adaptation in experimentally evolving wheat populations. Mol Ecol 2008, 17:930-943.

81. Rousset M, Bonnin I, Remoué C, Falque M, Rhoné B, Veyrieras J-B, Madur D, Murigneux A, Balfourier F, Gouis J, Santoni S, Goldringer I: Deciphering the genetics of flowering time by an association study on candidate genes in bread wheat (Triticum aestivum L.). Theor App/ Genet 2011, 123:907-926.

82. Gruntman E, Qi Y, Slotkin RK, Roeder T, Martienssen RA, Sachidanandam R: Kismeth: Analyzer of plant methylation states through bisulfite sequencing. BMC Bioinforma 2008, 9:371.

83. 84. ImageJ: U. S. National Institutes of Health. Bethesda, Maryland, USA. http://rsb.info.nih.gov/ij/.

84. Marino $\mathrm{JH}$, Cook P, Miller KS: Accurate and statistically verified quantification of relative mRNA abundances using SYBR Green I and real-time RT-PCR. J Immunol Methods 2003, 283:291-306.

85. Smit A, Hubley R, Green R: RepeatMasker Open-3.0. ; 1996.

doi:10.1186/1471-2229-13-209

Cite this article as: Khan et al:: Vernalization treatment induces site-specific DNA hypermethylation at the VERNALIZATION-A1 (VRN-A1) locus in hexaploid winter wheat. BMC Plant Biology 2013 13:209.

\section{Submit your next manuscript to BioMed Central and take full advantage of:}

- Convenient online submission

- Thorough peer review

- No space constraints or color figure charges

- Immediate publication on acceptance

- Inclusion in PubMed, CAS, Scopus and Google Scholar

- Research which is freely available for redistribution 